\title{
Dietary Modification of Thyroxine Deiodination in Rat Liver is Not Mediated by Hepatic Sulfhydryls
}

\author{
Laurence A. Gavin, Francis A. McMahon, and M. Moeller, Division of \\ Endocrinology-Metabolism, Veterans Administration Medical Center and \\ Department of Medicine, University of California, San Francisco, California 94121
}

\begin{abstract}
A B S TRACT The enzymatic deiodination of thyroxine $\left(\mathrm{T}_{4}\right)$ is thiol dependent. Fasting $(72 \mathrm{~h})$ depresses hepatic $\mathrm{T}_{4}$ deiodination and lowers the hepatic content of nonprotein sulfhydryls (NP-SH) and reduced glutathione $(\mathrm{GSH})$. It has been proposed that the fasting effect may be mediated through these alterations in hepatic sulfhydryls. To test the importance of tissue (hepatic) thiol content in the modification of $\mathrm{T}_{4}$ deiodination consequent to dietary manipulation, we examined the sequential deiodination of $\mathrm{T}_{4}$ to $3,5,3^{\prime}$ triiodothyronine $\left(\mathrm{T}_{3}\right)$ (5'-deiodination) and $3,3^{\prime}, 5-$ triiodothyronine (reverse $\mathrm{T}_{3}, \mathrm{rT}_{3}$ ) (5-deiodination) in liver homogenates without added thiol from groups of rats fed Purina lab chow (P) (a protein-rich diet), glucose alone $(G)$, or glucose plus cysteine $\left(G_{c}\right)$ for $72 \mathrm{~h}$ or fasted $(F)$ for the same period. The initial rate of each reaction was compared to the tissue concentrations of NP-SH and GSH.
\end{abstract}

Dietary manipulation induced significant changes in hepatic deiodination of $T_{4}$ to $T_{3}$ and $\mathrm{rT}_{3}$ and sulfhydryl content. There was a marked dissociation between the rate of each reaction and hepatic NP-SH and GSH levels. $\mathrm{T}_{4}$ deiodination by the alternative pathways was significantly higher $(P<0.01)$ in $\mathrm{G}>\mathrm{P}>\mathrm{F}$. In contrast both hepatic NP-SH and GSH concentrations were greater $(P<0.05)$ in $P>F>G$. The lack of a relationship between these parameters was further emphasized on analysis of tissue from rats fed $G_{c}$. Despite the clearcut $(P<0.01)$ increase in hepatic NP-SH and GSH consequent to $G_{c}$ feeding, there was no alteration in iodothyronine deiodination compared to the group fed glucose alone.

These data indicate that the effects of diet on $\mathrm{T}_{4}$ monodeiodination in liver are not mediated by changes in the tissue level of sulfhydryl compounds but rather involve alterations in the concentrations of the deiodinases.

\footnotetext{
Received for publication 11 December 1979 and in revised form 21 January 1980.
}

\section{INTRODUCTION}

Caloric intake appears to be a major physiological regulator of thyroid hormone activation. It has been demonstrated that both short-term fasting (1) and longterm starvation (2-4) significantly depress the circulating levels of $3,5,3^{\prime}$-triiodothyronine $\left(\mathrm{T}_{3}\right)^{1}$ and elevate $3,3^{\prime}, 5^{\prime}$-triiodothyronine (reverse- $\mathrm{T}_{3} ; \mathrm{rT}_{3}$ ) in man. In man these dietary induced changes in thyroxine $\left(\mathrm{T}_{4}\right)$ deiodination are a consequence of a decrease in the daily production of $\mathrm{T}_{3}$ and in the disposal of $\mathrm{rT}_{3}(2-4)$. Tissue studies in animals, particularly in the rat liver, tend to support these in vivo findings $(5,6)$.

The actual mechanisms by which fasting induces these changes have not been fully elucidated. Previous reports suggest that the effects of fasting result from a change in the concentration of deiodinase $(7,8)$ and/or in the availability of a cofactor $(9,10)$.

$\mathrm{T}_{4}$ deiodination is thiol dependent (11) and, as the tissue (hepatic) levels of nonprotein sulfhydryls (NP-SH) and reduced glutathione (GSH) are diminished in the fasted state (9), it has been proposed that the effect of fasting is mediated through a deficiency of these cofactors. It has been demonstrated that the effects of fasting on $\mathrm{T}_{4}$ deiodination to $\mathrm{T}_{3}$ can be reversed with the addition of an excess of thiol reagents in vitro $(9,10)$. However, we and others have failed to induce this reversal of the fasting effect $(7,8)$.

To test the importance of tissue (hepatic) thiol content in the modulation of $\mathrm{T}_{4}$ deiodination consequent to dietary modification, we examined the deiodinatino of $T_{4}$ to $T_{3}$ and $\mathrm{rT}_{3}$ in liver homogenate from rats fed a variety of diets or fasted for the same period. The specific activity of each reaction was compared to

\footnotetext{
'Abbreviations used in this paper: $\mathrm{F}$, fasted animals; G, animals fed $20 \%$ glucose in $\mathrm{H}_{2} \mathrm{O} ; \mathrm{G}_{\mathrm{c}}$, animals fed glucose plus levels of cysteine increasing from $0.25 \%, \mathrm{G}_{\mathrm{c}_{1}}$, to $0.5 \%, \mathrm{G}_{\mathrm{c}_{2}}$, and finally to $0.75 \%, \mathrm{G}_{\mathrm{c} 3}$; GSH, reduced glutathione; $\mathrm{NP}-\mathrm{SH}$, nonprotein sulfhydryls; $\mathrm{P}$, Purina-fed controls; $\mathrm{T}_{4}$, thyroxine; $\mathrm{T}_{3}, 3,5,3^{\prime}$-triiodothyronine; $\mathrm{rT}_{3}, 3,3^{\prime}, 5^{\prime}$-triodothyronine.
} 
the tissue content of NP-SH and GSH. The data suggest that the effect of fasting is mediated through a change in the concentration of deiodinase rather than in the availability of cofactor.

\section{METHODS}

$\mathrm{T}_{4}$ and $\mathrm{T}_{3}$ were obtained from Sigma Chemical Co., St. Louis, Mo. $\mathrm{rT}_{3}$ was generously provided by Dr. Eugene C. Jorgensen, University of California, San Francisco. ${ }^{125} \mathrm{I}-\mathrm{T}_{3}$ and ${ }^{125} \mathrm{I}-\mathrm{rT}_{3}$, each labeled in the phenolic ring position at specific radioactivities of $500-900 \mu \mathrm{Ci} / \mu \mathrm{g}$, were purchased from New England Nuclear, Boston, Mass. Goat anti-rabbit gammaglobulin serum was obtained from Antibodies Inc., Davis, Calif. $o$-phthaladehyde was purchased from Sigma Chemical Co., 5,5'-dithiobis-2-nitrobenzoic acid from Aldrich Chemical Co., Inc., Milwaukee, Wis., and EDTA was supplied by Eastman Organic Chemicals Div., Eastman Kodak, Rochester, N. Y. Other chemicals used were reagent grade and were purchased from commercial suppliers.

Animals and diets. Incubations were performed in hepatic preparations obtained from male Sprague-Dawley Rats. Within each experiment the rats (groups, $n=4$ ) were closely matched for weight and age. For $1 \mathrm{wk}$ before each study period the animals were maintained on an ad lib intake of $\mathrm{H}_{2} \mathrm{O}$ and Purina rodent laboratory chow; 5001 (25\% protein content) from Ralston Purina Co., St. Louis, Mo. Fasted animals (F) were totally deprived of calories $\left(\mathrm{H}_{2} \mathrm{O}\right.$ ad lib only) for $72 \mathrm{~h}$ before sacrifice, whereas fed controls were allowed access to food. In the initial experiments the controls ate Purina $(P)$ or drank $20 \%$ glucose in $\mathrm{H}_{2} \mathrm{O}(\mathrm{G})$. In later experiments a number of groups were fed glucose plus cysteine $\left(G_{c}\right)$ and compared to the glucose fed group. Diets were enriched with cysteine to increase the hepatic content of sulfhydryls. Cysteine was added to glucose at the following concentrations: $0.25 \%\left(\mathrm{G}_{\mathrm{c}_{1}}\right)$; $0.5 \%\left(\mathrm{G}_{\mathrm{c}_{2}}\right)$, and $0.75 \%\left(\mathrm{G}_{\mathrm{c}_{3}}\right)$.

Liver homogenization and incubation. Liver was homogenized ( $800 \mathrm{~g}$ pellet discarded) and $\mathrm{T}_{4}$ incubations performed as previously described (8). $\mathrm{T}_{4}(1 \mu \mathrm{M})$ deiodination to $\mathrm{T}_{3}$ was analyzed in $25 \%$ homogenate $(\mathrm{pH} 7.2)$, whereas $\mathrm{T}_{4}(1 \mu \mathrm{M})$ deiodination to $\mathrm{rT}_{3}$ was studied in $2 \%$ homogenate ( $\mathrm{pH} 8.5$ ) to facilitate optimum conditions. The buffer used for both incubations was $0.5 \mathrm{M}$ Tris-HCL that contained $0.25 \mathrm{M}$ sucrose and $10 \mathrm{mM}$ EDTA. The initial rate of each reaction was studied; samples $(100 \mu \mathrm{l})$ for analyses were removed from incubations $\left(37^{\circ} \mathrm{C}\right)$ at $5 \mathrm{~min}\left(\mathrm{~T}_{4}-\mathrm{rT}_{3}\right)$ and $15 \mathrm{~min}\left(\mathrm{~T}_{4}-\mathrm{T}_{3}\right)$ and added to $0.9 \mathrm{ml}$ of ice-cold, iodothyronine free, normal human serum (serum extracts). The respective triiodothyronines in the serum extracts were measured by the previously described specific radioimmunoassays (12). In each experiment the amount of product was corrected by the appropriate recovery and the amount of iodothyronine present in unincubated control tubes.

Analysis of hepatic GSH and NP-SH groups. The concentration of both GSH and NP-SH was measured in all homogenates using a modification of the methods described by Hissin and Hilf (13) for GSH and Sedlak and Lindsay (14) for NP-SH. A $2.5 \%$ homogenate was prepared in a $0.02 \mathrm{M}$ EDTA solution, ( $200 \mathrm{mg}$ liver in $8 \mathrm{ml} 0.02 \mathrm{M}$ EDTA). Aliquots were taken for protein estimation by the method of Lowry et al. (15). $4.5 \mathrm{ml}$ of homogenate was mixed with $1.5 \mathrm{ml} 25 \%$ $\mathrm{H}_{3} \mathrm{PO}_{3}$ in cellulose nitrate tubes $\left(1 / 2 \times 2 \frac{1}{2}\right.$ in.) to precipitate proteins. This preparation was centrifuged at $4^{\circ} \mathrm{C}$ at $100,000 \mathrm{~g}$ for $30 \mathrm{~min}$.

GSH assay. To $10 \mu \mathrm{l}$ of the $100,000 \mathrm{~g}$ supernate, $2 \mathrm{ml}$ of $0.1 \mathrm{M} \mathrm{PO}_{4}\left(13.8 \mathrm{~g} \mathrm{Na}_{2} \mathrm{NPO}_{4}+0.73 \mathrm{~g} \mathrm{NaH}_{2} \mathrm{PO}_{4}\right)$ containing $0.2 \mathrm{M}$ EDTA (pH 8.0) and $100 \mu \mathrm{l} o$-phthaladehyde were added. After thorough mixing and incubation at room temperature for $15 \mathrm{~min}$, the solutions were transferred to quartz curvettes. Fluorescence at $420 \mathrm{~nm}$ was determined with the activation at $350 \mathrm{~nm}$, on a Perkin-Elmer fluorescence spectrophotometer (Perkin-Elmer Corp., Instrument Div., Norwalk, Conn.). The GSH content was read off a standard curve (GSH: 5-100 $\mu \mathrm{M}$ ) and results expressed per milligram protein.

NP-SH assay. To $2 \mathrm{ml}$ of 100,000 supernate, $4 \mathrm{ml}$ of $0.4 \mathrm{M}$ Tris-HCL (pH 8.9) and $0.1 \mathrm{ml}$ of 5,5'-dithiobis-2-nitrobenzoic acid were added. After mixing and incubating at room air for $5 \mathrm{~min}$, the NP-SH content was determined colorimetrically at $412 \mathrm{~nm}$ on a Hitachi spectrophotometer (Hitachi America, Ltd., San Francisco, Calif.). Results were compared with those obtained from prepared standards. The NP-SH concentration was expressed per milligram protein.

Statistical methods. Mean values (mean $\pm \mathrm{SE}$ ) from experimental groups were compared to controls using Student's $t$ test for unpaired data.

\section{RESULTS}

Effects of dietary manipulation on body weight and serum glucose concentration. Table I demonstrates that body weight changes were significantly different for each dietary group. The P group gained weight, whereas both the $G$ and $F$ groups lost weight. Despite this difference, both $\mathrm{P}$ and $\mathrm{G}$ maintained normal blood glucose values. The mean serum glucose of fasted animals was significantly lower $(P<0.01)$ than in either of the fed groups.

Effects of dietary manipulation on serum $T_{4}$ and $T_{3}$

TABLE I

Effects of Dietary Modification on Body Weight, Serum Glucose, $T_{4}$ and $T_{3}($ mean $\pm S E M)$

\begin{tabular}{|c|c|c|c|c|c|c|}
\hline $\begin{array}{l}\text { Dietary } \\
\text { group }\end{array}$ & & $\begin{array}{l}\text { Number } \\
\text { of rats }\end{array}$ & $\begin{array}{c}\text { Percent body } \\
\text { weight } \\
\text { change }\end{array}$ & $\begin{array}{c}\text { Serum } \\
\text { glucose }\end{array}$ & $\mathrm{T}_{4}$ & $\mathrm{~T}_{3}$ \\
\hline & & & & $m g / d l$ & $\mu g / d l$ & $n g / m l$ \\
\hline Purina & $(\mathrm{P})$ & (12) & (t) $15 \pm 2$ & $131 \pm 6$ & $2.7 \pm .26$ & $0.43 \pm .03$ \\
\hline Glucose & (G) & (12) & $(-) 10 \pm 1$ & $112 \pm 7$ & $2.5 \pm .20$ & $0.53 \pm .04 \ddagger$ \\
\hline Fast $(72 \mathrm{~h})$ & $(\mathrm{F})$ & (12) & (-) $20 \pm 3$ & $89 \pm 3 *$ & $1.2 \pm .07^{*}$ & $0.24 \pm .01^{*}$ \\
\hline
\end{tabular}

$* P<0.01, \mathrm{~F}$ vs. fed.

$\downarrow P<0.05$, G vs. P. 
concentration. The $F$ group mean serum $T_{4}$ and $T_{3}$ values were significantly lower $(P<0.01)$ than the respective values in the fed groups (Table I). Although there was no difference between the mean serum $\mathrm{T}_{4}$ values for $P$ and $G$, the $T_{3}$ mean in $P$ was significantly less $(P<0.05)$ than in $G$. Regression analysis of all data revealed a lack of correlation between serum $\mathrm{T}_{3}$ and glucose values, $(r=-0.3, P>0.2)$.

Changes in hepatic $5^{\prime}$ and 5 deiodination. It is clear from Fig. 1 (left) that $T_{4}$ deiodination to $T_{3}$ and $\mathrm{rT}_{3}$ was significantly higher $(P<0.01)$ in $G$ compared to $P$. The rates of both reactions were lowest $(P<0.001)$ in the $\mathrm{F}$ group. Thus, the total deiodination of $\mathrm{T}_{4}$ by these alternative pathways was significantly different for each dietary group. Fig. 1 (right) illustrates that the hepatic content of NP-SH and GSH was significantly different $(P<0.01)$ between each of the three groups. The surprising finding, however, was that the levels of both of these compounds were lowest in $\mathrm{G}$. The hepatic sulfhydryl content was highest in P. A comparison between the hepatic content of sulfhydryls and the enzyme activities of $T_{4}$ deiodination to $T_{3}$ and $r T_{3}$ (Fig. 1) obviously demonstrates different patterns. This dissociation between hepatic sulfhydryls and $\mathrm{T}_{4}$ deiodination suggested that hepatic thiols were not regulatory under these conditions.

Changes in hepatic NP-SH and GSH in the $G_{c}$ group. Fig. 2 demonstrates the changes in hepatic NP-SH consequent to feeding the rats $20 \%$ glucose diets enriched with increasing amounts of cysteine. There was an increase $(P<0.001)$ in hepatic sulfhydryl at the highest dietary cysteine intake $\left(G_{\mathbf{c}_{3}}\right)$. A similar pattern was noted for the hepatic content of GSH. However, in spite of the increase in the tissue content of sulfhydryls, there was no change in hepatic $5^{\prime}$-deiodination rate $\left(\mathrm{T}_{4}\right.$ to $\left.\mathrm{T}_{3}\right)$, Fig. 2 . Similarly, the specific activities of $T_{4}$ deiodination to $\mathrm{rT}_{3}$ were not affected by the changes in the hepatic sulfhydryls secondary

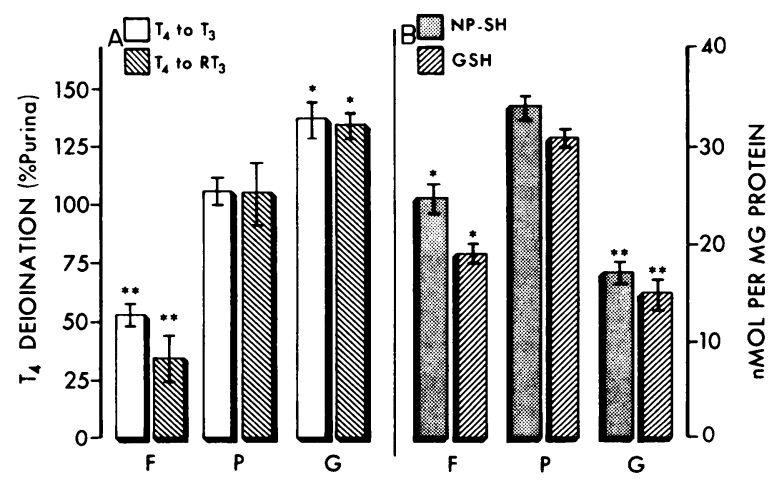

FIgure 1 A comparison between hepatic $T_{4}$ deiodination to $\mathrm{T}_{3} \alpha-\mathrm{rT}_{3}(\mathrm{~A})$ and liver content of NP-SH and reduced GSH, (B). The liver homogenate preparations were obtained from $\mathrm{P}, \mathrm{G}$, or $\mathrm{F}$ groups after $72 \mathrm{hj} . \$ P<0.01,{ }^{* *} P<0.01, \mathrm{G}$ and $\mathrm{F}$ vs. $P(A)$ and $F$ and $G$ vs. $P(B)$, respectively.

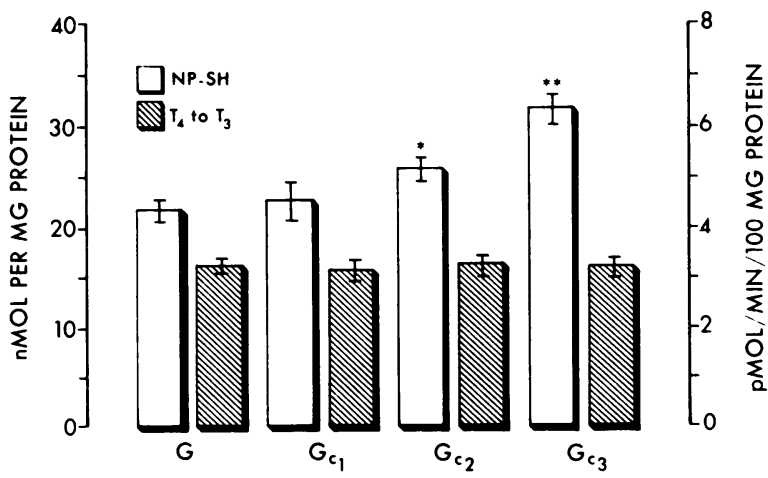

Figure 2 The effects of feeding groups of rats $(n=4)$ a $20 \%$ glucose diet alone (G group) or glucose enriched with cysteine $\left(\mathrm{G}_{\mathrm{C}}\right.$ group) on hepatic NP-SH and $\mathrm{T}_{4}$ deiodination to $\mathrm{T}_{3}$.

to cysteine feeding. There were no differences in body weight changes, serum glucose, $\mathrm{T}_{4}$ or $\mathrm{T}_{3}$ values in the $\mathrm{G}$ or $\mathrm{G}_{\mathrm{c}}$ groups.

Regression analysis of the data from the four dietary groups, $P, G, G_{c_{3}}$, and $F$ failed to reveal any correlation between the hepatic content of sulfhydryls and the specific enzyme activities.

\section{DISCUSSION}

This study demonstrates a lack of correlation between hepatic sulfhydryl content and the rate of iodothyronine deiodination. Each dietary group showed different concentrations of hepatic NP-SH, GSH, and specific deiodinase(s) activity, but there was discordance between these parameters.

A previous report had suggested a correlation between hepatic sulfhydryl levels and $T_{4}$ deiodination to $\mathrm{T}_{3}$. However, that study compared feeding a mixed diet with fasting for $48 \mathrm{~h}$ (9). The present report clearly demonstrates a dissociation between these parameters when feeding of specific diets (glucose or protein) is compared with fasting. This is supported by the data from the $G_{c}$ group. Thus, it is apparent that hepatic NP-SH and GSH are not the modulators of deiodinase(s) activity consequent to qualitative changes in dietary intake. Furthermore, the data indicate that these effects are mediated via alterations in deiodinase concentration rather than cofactor availability. Whether or not these alterations in 5' - and 5-deiodinase activity are the primary mediators of the dietary induced changes has not been elucidated. A recent publication demonstrated that the hepatic uptake of $\mathrm{T}_{4}$ may be the critical regulatory factor (16). Further studies are therefore warranted to determine which of these changes is dominant.

The present data is consistent with our previous report, which demonstrated that the addition of excess sulfhydryls failed to obliterate the differences in hepatic deiodinase(s) activity noted between a $G$ and a 
$72 \mathrm{~h} \mathrm{~F}$ group (8) and a similar study of Kaplan et al. (7), who compared a $\mathrm{P}$ to a 72-h F group (7). Balsam et al. (10) did note that it was possible to reverse the difference in $T_{4}$ deiodination to $T_{3}$ between a $48-h F$ group and a group fed laboratory chow, by adding GSH in vitro; however, these studies were performed in tissue preparations from $\mathrm{T}_{4}$-treated animals (10). Therefore, in the rat, the combination of "chemical hypothyroidism" (low serum $\mathrm{T}_{4}$ ) and the caloric deprivation induced by fasting apparently affects both deiodinase and cofactor (sulfhydryl) concentration.

However, the difference between $G$ and $P$ cannot be attributed to a hypothyroid state as the mean serum $\mathrm{T}_{4}$ was the same in both groups. Furthermore, the hepatic sulfhydryl concentration was less $(P<0.001)$ in $\mathrm{G}$ compared to $\mathrm{P}$ and in addition the diet-induced increase (glucose plus cysteine) in hepatic NP-SH and GSH did not alter the iodothyronine deiodination. The greater activity of $T_{4}$ deiodination (to $T_{3}$ and to $\mathrm{rT}_{3}$ ) in $\mathrm{G}$ cannot be attributed to differences in triiodothyronine degradation. The metabolism of both $\mathrm{T}_{3}$ and $\mathrm{rT}_{3}$ to $3,3^{\prime}-\mathrm{T}_{2}$ were similar in $\mathrm{G}$ and $\mathrm{P}$ (unpublished observation).

The observed alterations in hepatic deiodinase activities $(G>P)$ can account for the higher serum $T_{3}$ values in $G$ compared to $P$. The previously noted higher serum $T_{3}$ values in man (17) and rat (18) fed carbohydrates compared to protein are probably due to a similar mechanism. It has also been demonstrated that refeeding with carbohydrate rather than protein in fasted man and rat reverses the effects of fasting on serum $T_{3}$ and $T_{3}$ generation from $T_{4}(1,6)$.

In conclusion, this report shows that there is a lack of correlation between hepatic sulfhydryls and iodothyronine deiodinase activity in groups of rats fed a variety of diets or fasted for an equivalent period and that the dietary effects are not mediated via alterations in hepatic thiols but are probably modulated through changes in the concentration of deiodinase enzymes.

\section{ACKNOWLEDGMENTS}

This study was supported by the research division of the Veterans Administration and grant AM 24013-01 from the National Institutes of Health.

\section{REFERENCES}

1. Azizi, F. 1978. Effect of dietary composition on fasting induced changes in serum thyroid hormones and thyrotropin. Metab. Clin. Exp. 27: 935-942.

2. Vagenakis, A. G., G. I. Portnay, J. T. O'Brien, M. Rudolph, R. A. Arky, S. H. Ingbar, and L. E. Braverman. 1977. Effect of starvation on the production and metabolism of thyroxine and triiodothyronine in euthyroid obese patients. J. Clin. Endocrinol. Metab. 45: 1305-1309.

3. Eisenstein, A., S. Hagg, A. G. Vagenakis, S. L. Fang, B. Ransil, A. Burger, A. Balsam, L. E. Braverman, and S. H.
Ingbar. 1978. Effect of starvation on the production and peripheral metabolism of $3,3^{\prime} 5^{\prime}$-triiodothyronine in euthyroid obese subjects. J. Clin. Endocrinol. Metab. 47: 889-893.

4. Suda, A. K., C. S. Pittman, T. Shimizu, and J. B. Chambers. 1978. The production and metabolism of 3,5,3'-triiodothyronine and 3,3',5'-triiodothyronine in normal and fasting subjects. J. Clin. Endocrinol. Metab. 47: 11311319.

5. Kaplan, M. M., and R. D. Utiger. 1978. Iodothyronine metabolism in rat liver homogenates. J. Clin Invest. 61 : $459-471$.

6. Harris, A. R., S. W. Fang, A. G. Vagenakis, and L. E. Braverman. 1978. Effect of starvation, nutrient replacement and hypothyroidism on in vitro hepatic $T_{4}$ to $T_{3}$ conversion in the rat. Metab. Clin. Exp. 27: 1680-1690.

7. Kaplan, M. M. 1979. Subcellular alterations causing reduced hepatic thyroxine 5 '-monodeiodination activity in fasted rats. Endocrinology. 104: 58-64.

8. Gavin, L. A., F. Bui, F. McMahon, and R. R. Cavalieri, 1980. Sequential deiodination of thyroxine to $3,3^{\prime}$ diiodothyronine via $3,5,3^{\prime}$-triiodothyronine and $3,3^{\prime}, 5^{\prime}$ triiodothyronine in rat liver homogenate: the effects of fasting vs glucose feeding. J. Biol. Chem. 255: 49-54.

9. Harris, A. R., S. L. Fang, L. Hinerfeld, L. Braverman, and A. G. Vagenakis. 1979. The role of sulfhydryl groups on the impaired hepatic 3,5,3'-triiodothyronine generation from thyroxine in the hypothyroid, starved, fetal and neonatal rodent. J. Clin. Invest. 63: 516-524.

10. Balsam, A. and S. H. Ingbar. 1979. Observations on the factors that control the generation of $T_{3}$ from $T_{4}$ in rat liver and the nature of the defect induced by fasting. $J$. Clin. Invest. 63: 1145-1156.

11. Visser, T. J., I. V. Does-Tobe, R. Doctor, and G. Hennemann. 1976. Subcellular localization of a rat liver enzyme converting thyroxine to triiodothyronine and possible involvement of essential thiol groups. Biochem. J. 157: 479-482.

12. Gavin, L. A., J. N. Castle, F. A. McMahon, P. Martin, M. E. Hammond, and R. R. Cavalieri. 1977. Extrathyroidal conversion of thyroxine to $3,3^{\prime}, 5^{\prime}$-triiodothyronine (reverse- $\left.\mathrm{T}_{3}\right)$ and to 3,5,3'-triiodothyronine $\left(\mathrm{T}_{3}\right)$ in humans. J. Clin. Endocrinol. Metab. 44: 733-742.

13. Hissin, P. J., and R. Hilf. 1976. A fluorometric method for determination of oxidized and reduced glutathione in tissues. Anal. Biochem. 74: 214-226.

14. Sedlak, J., and R. H. Lindsay. 1968. Estimation of total, protein-bound, and non-protein sulfhydryl groups in tissue with Ellman's Reagent. Anal. Biochem. 25: 192-205.

15. Lowry, O. H., N. J. Rosebough, A. L. Farr, and J. Randall. 1951. Protein measurement with Folin phenol reagent. J. Biol. Chem. 193: 265-275.

16. Jennings, A. S., D. C. Ferguson, and R. D. Utiger. 1979. Regulation of the conversion of thyroxine to triiodothyronine in the perfused rat liver. J. Clin. Invest. 64: $1614-1623$.

17. Spaulding, S. W., I. J. Chopra, R. S. Sherwin, and S. S. Lyall. 1976. Effect of caloric restriction and dietary composition on serum $\mathrm{T}_{3}$ and reverse $\mathrm{T}_{3}$ in man. J. Clin. Endocrinol. 42: 197-200.

18. Glass, R. G., R. Mellitt, K. D. Burman, L. Wartofsky, and R. S. Swerdloff. 1978. Serum triiodothyronine in undernourished rats: dependence on dietary composition rather than total caloric or protein intake. Endocrinology. 102: 1925-1928. 